\title{
Association between Doctor's Motivation, Age, and Leadership on Patient's Satisfaction: A Path Analysis Evidence
}

\author{
Lukman Aryoseto'), Didik Tamtomo², Bhisma Murti1) \\ 1)Masters Program in Public Health,Universitas Sebelas Maret \\ ${ }^{2)}$ Faculty of Medicine, Universitas Sebelas Maret
}

\begin{abstract}
Background: Quality health care needs are increasing. The service quality of one public health center andanother does not have the same standard yet. One of the factors that influence the assessment of service quality is the patient satisfaction. Several factors can influence patient satisfaction, especially from the doctor's side. This study aims to determine the effect of physician motivation, the age of the doctor, and the head of the health center on physician job satisfaction and patient satisfaction.

Method: This was an analytic observational study with a cross-sectional design. The study was conducted at community health centers in Karanganyar and Surakarta, Central Java, in August 2018. A total of 25 doctors and 225 patients were selected using proportional random sampling. The dependent variable in this study is patient satisfaction. The independent variables in this study were doctor's motivation, doctor's work satisfaction, doctor's age, and the head of the health center. Data were obtained using questionnaires and analyzed using path analysis.

Results: Patient satisfaction was directly increased by by the doctor's work satisfaction $(b=0.10$; $\mathrm{SE}=0.02 ; \mathrm{p}<0.001)$ but decreased by doctor's age $(\mathrm{b}=-0.82 ; \mathrm{SE}=0.02 ; \mathrm{p}<0.001)$. Patient satisfaction was indirectly affected by doctors' motivation and head of community health center.

Conclusions: Patient satisfaction is directly increased by by the doctor's work satisfaction but decreases by doctor's age. Patient satisfaction is indirectly affected by doctors' motivation and head of community health center.
\end{abstract}

Keywords: patient satisfaction, doctor's motivation, leadership, community health center

Correspondence:

Lukman Aryoseto. Masters Program in Public Health, Universitas Sebelas Maret. Jl. Ir. Sutami 36A, Surakarta 57126, Central Java, Indonesia. Email: lukmanaryoseto@gmail.com

\section{BACKGROUND}

The quality of health services in the era of National Health Insurance (JKN) still needs to be studied. Based on the study by Widiastuti et al. (2015) in Bali, there were differences in the level of patient satisfaction with First Level Health Facilities (FKTP). The highest satisfaction was felt by patients who came to general practitioners and health centers, while the lowest level of satisfaction was found in private clinics. The difference in the level of satisfaction is also influenced by changes in the health insurance organizing body, namely that currently many patients with ex-ASKES members feel a decrease in the quality of health facility services (health facilities) (Setiawati and Sunjaya, 2016).

Good health is supported by good quality health facilities. Several factors can influence the assessment of service quality of a health facility. One of the factors is the existence of good human resource management. Doctors, as one of the human resources in health facilities, have a wider role in the JKN era. Doctors have an important role in every health service because the performance of doctors is one indicator of the success in administering JKN. Doctor coaching management in order for the 
doctors to be able to carry out their work is very necessary, so the doctors are able to contribute to the progress of the health center (RI Ministry of Health, 2015).

Public Health Center is one of the FKTP that serves the community at the sub-district level. Health services provided by the health center include healing for consumers who are sick or for consumers who need health consultations and efforts to prevent various diseases and improve health (RI Ministry of Health, 2015). Based on research by Gaynor et al. (2015), that an organization will be competitive based on the management of labor or human resources, so that the management of doctors as a resource is one of the strategic factors in a health center.

Doctors who work at PHC must provide the best service. Doctors who work in a health service cannot be separated from the influence of motivation in work. Motivation can be defined as a process that explains the intensity of an individual, the direction and perseverance of a business to achieve a goal, based on the need. The strength of a doctor's motivation will affect the quality of the action to be carried out, one of which is the performance of a doctor, but motivation is not the only factor that influences performance, because an individual will act and interact with other mediation processes and the environment. Some of the factors that can influence motivation include workers feeling challenges in doing work, encouragement from the leadership, good selfefficacy, and encouragement in meeting needs (Luthan, 1998; Robbins, 2008).

Based on Cahyani's research (2011), the doctor's performance was considered to be lacking. Some of the things that were assessed include the presence of doctors not according to schedule (65\%), doctors difficulty to contact (15\%), and examination by doctors which is too fast (20\%) (Nurha- yani, 2006). The doctor's performance is still lacking, one of which is due to low job satisfaction. According to Locke and Lathan (1976 in Tella et al., 2007),it shows that job satisfaction is a pleasant or positive emotional state that results from an assessment by people who have done their work. Job satisfaction is also a result of the perceptions or attitudes of employees based on how well their work provides things that are considered important. Etamadi (2004 in Khalatbari, 2013) argues that job satisfaction is one of the important factors in improving performance and cause positive views from individuals about their work, which correlates with salary levels, social values of work and working environment conditions. Doctor's job satisfaction in Indonesia is also influenced by the provision of fair services, complete equipment, the existence of morning reports for cases in certain patients, always evaluating performance, providing opportunities to improve competence (Nurhayani, 2006; Ratnamiasih, 2012).

There is a relationship between job satisfaction and service quality. If the job satisfaction of an agency increases, the service quality will also increase. Based on the study by Szecsenyi et al. (2011) in Germany, it was found that there was a significant relationship between service quality and non-physician employee job satisfaction, while service quality was not related to physician job satisfaction. Research from Cahyani (2011) explains different things where the presence of doctor's job satisfaction will improve performance so that it will improve the quality of services that are assessed based on patient satisfaction. The research of Mirshanti et al. (2017) explains that there is a relationship between patient satisfaction and service quality, where the higher patient satisfaction will improve the assessment of 
service quality in the puskesmas. This study aims to explain some of the relationships of factors that influence physician job satisfaction and patient satisfaction at $\mathrm{PHC}$, including the age of the doctor, motivation of the doctor and the head of PHC.

\section{SUBJECTS AND METHOD \\ a. Study Design \\ This was an analytic observational study with a cross sectional design. The study was conducted at 25 community health centers in Surakarta and Karanganyar, Central Java, in August 2018.}

\section{b. Population and Sample}

The population in this study consists of doctors and patients at PHC. The sampling technique that will be used in this study is multistage sampling, which consists of consecutive sampling to select 25 from 38 PHC in Surakarta and Karanganyar, and proportional random sampling to get 25 doctors and 225 patients proportionally from each selected previous PHC.

\section{c. Study Variables}

The dependent variable was patient satisfaction. The independent variables were doctor's motivation, doctor's job satisfaction, the age of the doctor, and the head of community health center.

\section{d. Operational Definition of Variables}

Doctor's work motivation was defined as a number of internal and external encouragement from an individual which causes the emergence of an enthusiastic attitude in working and carrying out health services in a wellness center.

The doctor's age was defined as the age of the doctor working in the health center, calculated from the year of birth to the time the study was conducted. Doctor's job satisfaction was defined as perceptions felt by doctors about the work they have done.
Head of community health center was defined as the result of the doctor's perception of the head of PHC where they work. Patient satisfaction was defined as a patient's feeling of pleasure which was obtained from a comparison between the services he obtained and his expectations.

\section{e. Study Instruments}

Data on physician work motivation, physician job satisfaction, age of doctors and health center leaders in this study were obtained from questionnaires given to doctors. Patient satisfaction data were obtained using questionnaires distributed to patients who had left the general treatment room and were waiting for drugs in the pharmaceutical department.

\section{f. Data Analysis}

Univariate analysis was conducted to see the frequency distribution and characteristics of the percentage of the study subjects. Bivariate analysis was conducted to study the relationship between patient satisfaction and independent variables using the chi-square method. Furthermore, multivariate analysis using path analysis was used to determine the direct effect and indirect effects of the dependent and independent variables.

\section{RESULTS \\ 1. Univariate Analysis}

The number of samples obtained and fulfilling the inclusion and exclusion criteria was 25 doctors and 225 patients as respondents. The characteristics of the respondents in this study are illustrated in Table 1.

Table 1 showes that the gender of the study subjects both were 119 (52.9\%) males and females were 106 (47.1\%). The average age of patients was 34.64. The education level of the majority of respondents had received education $\geq$ high school consisting of 172 (76.4\%), education <senior high 
school was 53 (23.6\%). The number of ptients who did not use insurance were 67 (29.8\%) respondents, who used non-BPI
BPJS amount to 54 (24.0), and those using BPI BPJS amount to 104 (46.2\%).

Table 1. Sample characteristics

\begin{tabular}{lcccc}
\hline Variable & Characteristics & Mean \pm SD & n & $(\%)$ \\
\hline Gender & Male & - & 119 & 52.9 \\
Age of patient & Female & - & 106 & 47.1 \\
Age of doctor & & $34.64 \pm 11.60$ & & \\
Patient education & & $39.24 \pm 4.87$ & & \\
& & - & 53 & 23.6 \\
Status of patient insurance & LSHS & - & 172 & 76.4 \\
& No insurence & - & 67 & 29.8 \\
& BPJS non-BPI & - & 54 & 24.0 \\
& BPJS BPI & - & 104 & 46.2 \\
\hline
\end{tabular}

\section{Bivariate Analysis}

Bivariateanalysis was used to analyze the relationship between doctor's motivation, doctor's work satisfaction, doctor's age, and

Table 2. The results bivariate analysis

\begin{tabular}{lcc}
\hline \multicolumn{1}{c}{ Independent Variable } & $\mathbf{r}$ & $\mathbf{p}$ \\
\hline Doctor's motivation & 0.31 & $<0.001$ \\
Doctor's work satisfaction & 0.48 & $<0.001$ \\
Doctor's age & -0.16 & 0.014 \\
Health center leader & 0.35 & $<0.001$ \\
\hline
\end{tabular}

Table 2 showed that there was a significant relationship between doctor's motivation $(\mathrm{r}=0.31 ; \mathrm{p}<0.001)$, doctor's work satisfaction $(\mathrm{r}=0.48 ; \mathrm{p}<0.001)$, doctor's age $(\mathrm{r}=-$ $0.16 ; \mathrm{p}=0.014)$, and head of community health center $(r=0.35 ; p<0.001)$ were associated with patient satisfaction.

\section{Path Analysis}

\section{a. Model Specifications}

Model specifications were used to describe the relationships between the variables studied. Observed variables consisted of doctor's motivation, doctor's job satisfaction, doctor's age, health center leader, and patient's satisfaction.

\section{b. Model Identification}

Measurement variables included:

1) Number of measured variables $=5$

2) Endogenous variable $=2$

3) Exogenous variable $=5$

4) Number of parameters $=8$ health center leader with patient's satisfaction. The result of bivariateanalysis was shown in Table 2.
The degree of freedom was:

$\mathrm{df}=$ (number of measured variables $\mathrm{x}$ $($ number of measured variables +1$)$ ) $/ 2-$ (endogenous variable + exogenous variable + number of parameters)

$=(5 \times(5+1)) / 2-(2+3+8)$

$=15-13=2$

The result of the degree of freedom (df) was 2 which mean over identified or path analysis can be done.

Figure 1 showed the structural model after estimation by using the Amos SPSS program. The indicator that showed the suitability of the model in Figure 1 was the result of the CMIN (Normed Chi Square) fit index of 1.739 with $\mathrm{p}=0.40(>0.05)$; NFI (Normed Fit Index) $=0.99(\geq 0.90)$; CFI (Comparative Fit Index $)=0.99(\geq 0.90)$; GFI (Goodness of Fit Index) $=0.99(\geq$ 0.90); RMSEA (Root Mean Square Error of Approximation) $<0.001 \quad(\leq 0.08$. $)$ These 
scores indicated that the model fulfilled the empirical data. criteria specified and it was according to

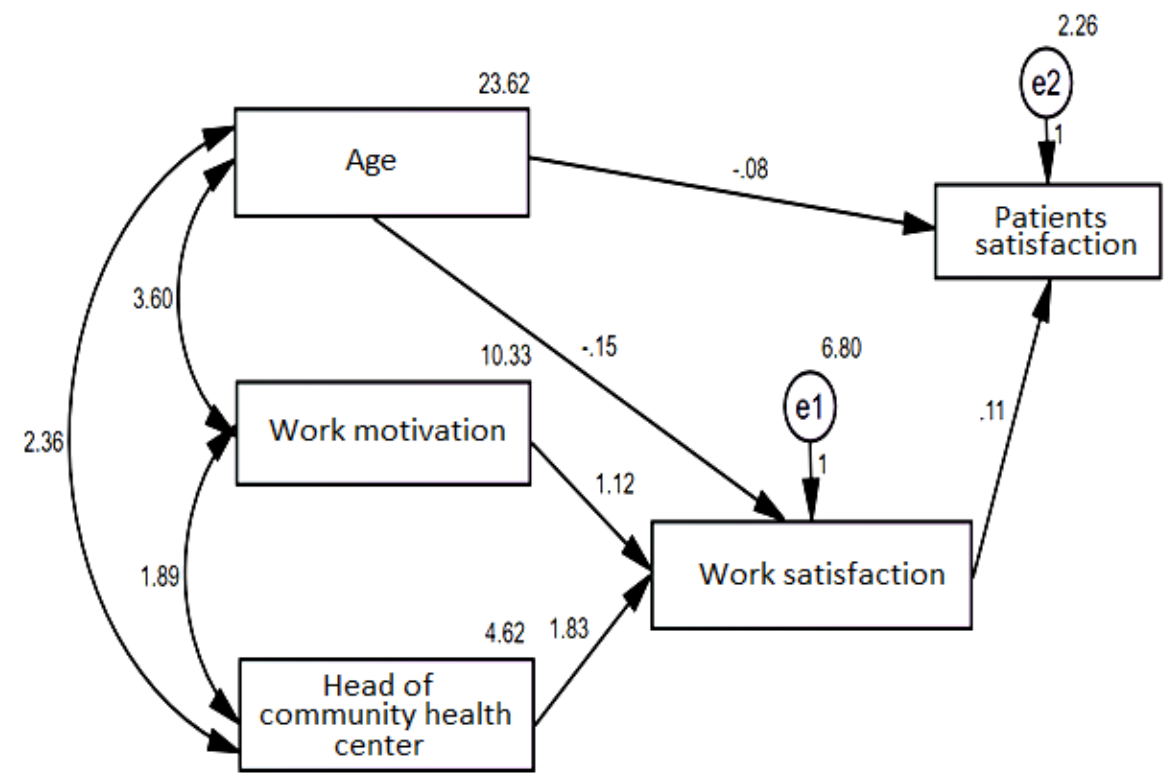

Figure 1. Structural model of path analysis

Table 3.The results of path analysis

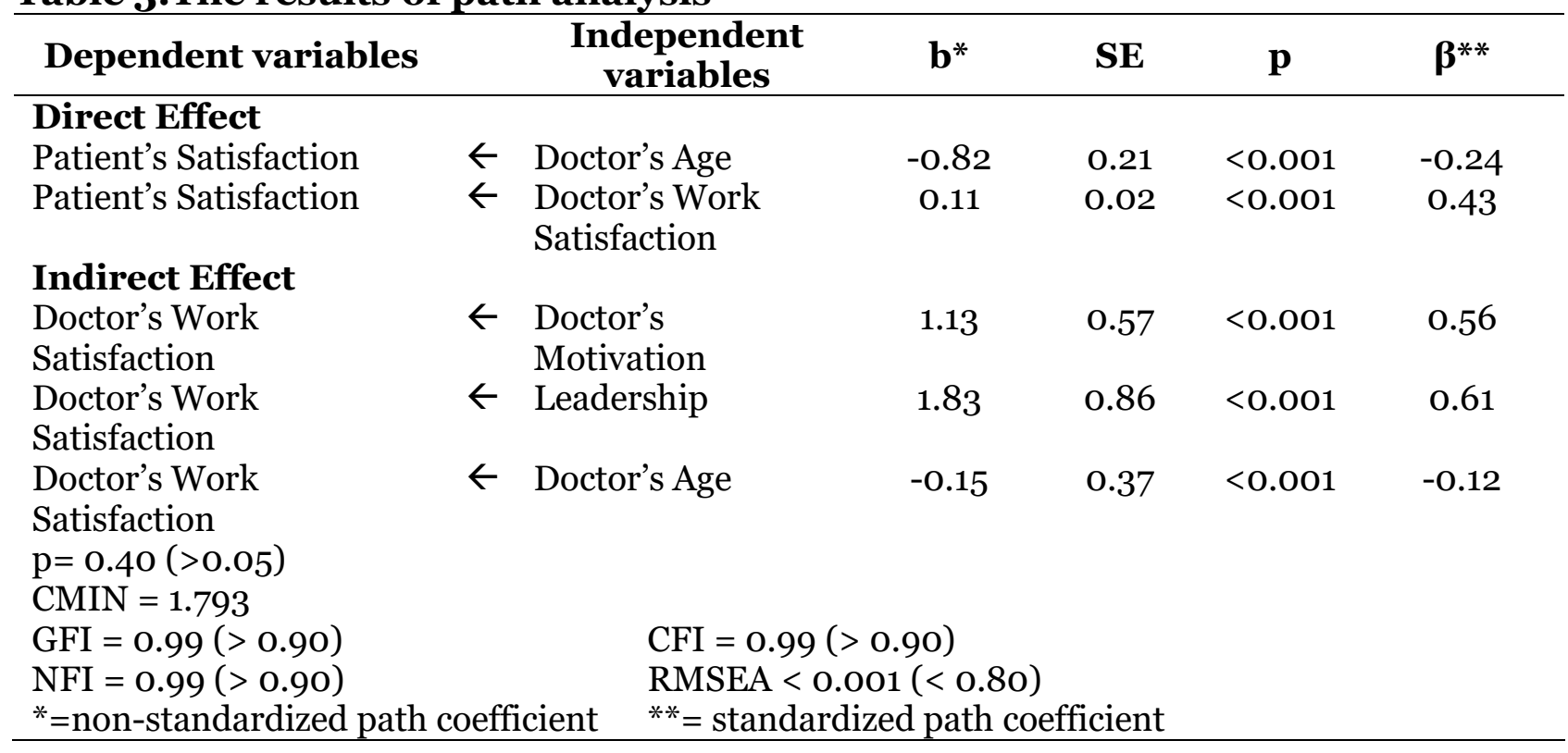

Table 3 explained that doctor's work satisfaction can be influenced by three things, namely the motivation of the doctor, the age of the doctor and the head of the health center. Every increase in one unit of doctor's motivation would increase the doctor's job satisfaction by 1.13. Each increase in one unit of leadership would increase the doctor's work satisfaction by 1.83 . Each increase in one unit of doctor's age would reduce the doctor's work satisfaction by 0.15. Patient satisfaction was influenced by the age of the doctor and the doctor's work satisfaction. Every increase in one unit of the doctor's age would reduce patient's satisfaction by 0.82 . Every increase in one unit of doctor's work satisfaction would increase patient's satisfaction by 0.11 . 


\section{DISCUSSION \\ 1. The effect of doctor's motivation on doctor's work satisfaction}

The results of the path analysis showed that there was an effect of doctors' motivation on doctor's job satisfaction in the health center and it was statistically significant. The higher the doctor's motivation, the greater the doctor's work satisfaction in the community health center.

The result of this study was in line with a study done by Roosand Van Eden (2008). The study explained that work motivation influenced the doctor's work satisfaction. The study explained that motivation to fulfill the needs significantly affected job satisfaction for the work that has been done. Some extrinsic and intrinsic motivation factors influenced the increase in job satisfaction, including remuneration, cooperation between employees, and work facilities provided (Ahmed et al., 2010; MafiniandDlodlo, 2014).

\section{The effect of doctor's age on doc- tor's work satisfaction}

The results of the path analysis showed that there was an effect of doctors' age on doctor's job satisfaction in the health center and it was statistically significant.The older the age of the doctor, the lower the doctor's work satisfaction.

Kooijet al. (2010), Lorber and Skela (2012) in their studies explained thatage affected employee's job satisfaction and commitment, where the older the age would increase the desire for salary increases, promotions and increase in facilities. If these things cannot be fulfilled by the agency, it would reduce someone's satisfaction and commitment to work in the agency.

Nowadays, young doctors prioritized to work as specialist doctors rather than general practitioners who worked in primary care (Smith, 2005). A study of Hayes and Shakya (2013) also explained that there were only nine out of 1137 young doctors who chose to work in primary care, while the rest chose to work as specialists. Therefore, the older the age, the smaller the opportunity to become a specialist, it can affect the job satisfaction of a doctor in primary care, especially a health center.

\section{The effect of health of community health center on doctor's work satisfaction}

The results of the path analysis showed that there was an effect of health center leader on doctor's job satisfaction in the health center and it was statistically significant. The better the head of the health center, the higher the doctor's job satisfaction at the health center.

The result of this study was in line with a study by Watson (2009). The study explained that leaders have a positive influence on employee's job satisfaction. The better the leader, the higher the job satisfaction of the employee and it would ultimately improve the performance of the agency. The similar idea was found in the study of Lorber and SkelaSavič (2012). The study explained that the head of the health service center was asked to always monitor the job satisfaction of the employees, because this can affect patient's satisfaction, where patient satisfaction was one of the aspects of the service's assessment. A study by Khan and Nemati (2011) and Platis et al. (2015) also explained that there was a relationship between leadership, workplace conditions and career development opportunities that influenced employyee's job satisfaction.

\section{The effect of doctor's age on patient's satisfaction}

The results of the path analysis showed that there was an effect of doctor's age on patient's satisfaction in the health center and it was statistically significant. The older 
the age of the doctor, the lower the patient's satisfaction at the health center.

A study done by Shah and Ogden (2006) stated thatpatients tend to trust young doctors, because younger doctors who work in health centers can explain the patient's condition more carefully, prefer to discuss with patients about alternative examinations and therapies that patients can choose.

\section{The effect of doctor's work satis- faction on patient's satisfaction}

The results of the path analysis showed that there was an effect of doctor's work satisfaction on patient's satisfaction in the health center and it was statistically significant. The higher the doctor's work satisfaction, the greater thepatient's satisfaction in the health center.

The result of this study was in line with a study done by Wenget al. (2011) which stated that there was a relationship between doctor's work satisfaction and the services provided. A study by Sujianto et al. (2011) also explained the same thing, high doctor's work satisfaction would affect the enhancement of patient's satisfaction to the health services provided. A study conducted in Blitar explained that the better the doctor's job satisfaction, the better the performance and it would ultimately improve patients' satisfaction so as to improve service quality. Based on some of the studies, it can be concluded that the higher the doctor's job satisfaction, the higher the patient's satisfaction to health services received at the health center.

\section{REFERENCES}

$\overline{\text { Ahmed I, Nawaz MM, Iqbal N, Ali I, Shau- }}$ kat Z, Usman A (2010). Effects of motivational factors on employyees' job satisfaction a case study of University of the Punjab, Pakistan. Inter- national journal of business and management, 5(3): 70.

Cahyani A (2011). Pengaruh kepuasan kerja terhadap kinerja dokter di ruang rawat inap RSU Daerah Jayapura. Thesis: Universitas Hasanuddin.

Gaynor M, Ho K, Town RJ (2015). The industrial organization of health-care markets. Journal of Economic Literature, 53(2): 235-84.

Hayes BW, Shakya R (2013). Career choices and what influences Nepali medical students and young doctors: a crosssectional study. Human resources for health, 11(1): 5 .

Kementrian Kesehatan Republik Indonesia (2015). Peraturan Menteri Kesehatan Republik Indonesia Nomor 46 Tahun 2015. Jakarta.

Khalatbari J, Ghorbanshiroudia S, Firouzbakhsha M (2013). Correlation of job stress, job satisfaction, job motivation dan burnout dan feeling stress. Procedia-Social dan Behavioral Sciences 84: $860-863$.

Khan K, Nemati AR (2011). Impact of job involvement on employee satisfaction: A study based on medical doctors working at Riphah International University Teaching Hospitals in Pakistan. African Journal of Business Management, 5(6): 2241-2246.

Kooij DT, Jansen PG, Dikkers JS, De Lange $\mathrm{AH}$ (2010). The influence of age on the associations between HR practices and both affective commitment and job satisfaction: A meta-analysis. Journal of Organizational Behavior, 31(8): 1111-1136.

Lorber M, Skela SB (2012). Job satisfaction of nurses and identifying factors of job satisfaction in Slovenian Hospitals. Croatian medical journal, 53(3): 263-270. 
Luthans F (1998). Organisational Behaviour. 8th ed. Boston: Irwin McGrawHill.

Mafini C, Dlodlo N (2014). The relationship between extrinsic motivation, job satisfaction and life satisfaction among employees in a public organisation. SA Journal of Industrial Psychology, 40(1): 01-12.

Mirshanti, F, Tamtomo D, Murti B (2017). The asssociations between accreditation status, patient socioeconomic factors, insurance type, patient perceived quality of service, and satisfaction at community health center. Journal of Health Policy and Management, 2(1): 91-101.

Nurhayani S (2006). Beberapa Faktor Yang Berhubungan dengan Kepuasan Kerja Dokter Spesialis di Poliklinik Rawat Jalan RSU dr. Kanujoso Djatiwibowo Kota Balikpapan Tahun 2006. Thesis: UniversitasDiponegoro.

Platis C, Reklitis P, Zimeras S (2015). Relation between job satisfaction and job performance in healthcare services. Procedia-Social and Behavioral Sciences, 175: 480-487.

Ratnamiasih I, Govindaraju R, Prihartono B, Sudirman I (2012). Kompetensi SDM dan kualitas pelayanan rumah sakit. Trikonomika, 11(1): 49-57.

Robbins SP, Judge TA (2008). Perilaku Organisasi Edisi 12. Edisi bahasa Indonesia Buku 1. Jakarta: Salemba Empat.

Roos W, Van Eeden R (2008). The relationship between employee motivation, job satisfaction and corporate culture. SA Journal of Industrial Psychology, 34(1): 54-63.

Setiawati EP, Sunjaya D (2016). Perbandingan Kepuasan Pasien Eks ASKES dan Non-ASKES di Puskesmas Pada
Implementasi Jaminan Kesehatan Nasional. Jurnal Sistem Kesehatan, 1(3).

Shah R, Ogden J (2006). What's in a face? The role of doctor ethnicity, age and gender in the formation of patients' judgements: an experimental study. Patient education and counseling, 6o(2): 136-141.

Smith LG (2005). Medical professionalism and the generation gap. The American journal of medicine, 118(4): 439-442.

Sujianto, Koeswo M, Woro E (2014). Kepuasan kerja mempengaruhi kinerja pelayanan operasi elektif. Jurnal Kedokteran Brawijaya. 28:1.

Szecsenyi J, Goetz K, Campbell S, Broge B, Reuschenbach B, Wensing M (2011). Is the job satisfaction of primary care team members associated with patient satisfaction?. BMJ quality dan safety, bmjqs-2009.

Tella A, Ayeni CO,Popoola SO (2017). Work motivation, job satisfaction, dan organisational commitment of library personnel in academic dan research libraries in Oyo State, Nigeria. Library Philosophy dan Practice (e-journal).

Watson LM (2009). Leadership's influence on job satisfaction. Radiologic Technology, 8o(4): 297-308.

Widiastuti NM, Nopiyani NMS, Karmaya M (2015). Perbedaan Kepuasan Pasien Jaminan Kesehatan Nasional pada Empat Jenis Fasilitas Kesehatan Tingkat Pertama. Public Health dan Preventive Medicine Archive.3(2).

Weng HC, Hung CM, Liu YT, Cheng YJ, Yen CY, Chang CC, Huang CK (2011). Associations between emotional intelligence dan doctor burnout, job satisfaction dan patient satisfaction. Medical education, 45(8): 835-842. 